Amos C. Fox*

\title{
Russian hybrid warfare: A framework
}

DOI 10.2478/jms-2021-0004

Received: December 07, 2018; Accepted: March 08, 2021

Abstract: As Montenegro sough to the North Atlantic Treaty Organization (NATO) in 2015, an attempted coup erupted within the country in October of that year. The Telegraph's Ben Farmer reported that, 'An officer with Russia's GRU military intelligence service, is accused of running a web of Serbian and Russian nationalists and paramilitaries who plotted to assassinate the Montenegrin prime minister.' ${ }^{1}$ The failed coup and attempted assassination were conducted by Russian intelligence in support of Russian President Vladimir Putin's vision for a modern Eurasia in which NATO discontinues encroaching on Russia's sphere of influence and in which Russia ascends to regional hegemony. ${ }^{2}$

Although unsuccessful, this covert operationconducted by Russian intelligence working in conjunction with disaffected Russian partisans within Montenegro-to stymie NATO's expansion captures the essence of modern Russian hybrid warfare. Nevertheless, Montenegro is not unique, but instead is one of many recent hybrid conflicts propagated by the Russian government. Speaking on the spectre of Russian operations in Eastern Europe, American general Michael Williamson commented, 'In terms of state-based challenges, Russia's purported annexation of Crimea and invasion of Ukraine demonstrated a sophisticated combination of diplomatic, informational, military, and economic means to achieve objectives below a threshold that the Russian leadership believe would elicit a concerted NATO response. ${ }^{3}$

1 Farmer, B. (2017, February 26). Montenegro to Indict Russian Spy Behind Coup Plot. The Telegraph. Available at: http://www. telegraph.co.uk/news/2017/02/26/montenegro-indict-russian-spybehind-coup-plot/. [accessed 5 March, 2017].

2 Knezevic, G. (2017, January 2). Montenegro's NATO-Russia Chess Match. Radio Free Europe/Radio Liberty. Available at: http://www. rferl.org/a/montenegro-nato-russia-chess-match/28210094.html. [accessed 5 March, 2017].

3 Lt. Gen. Michael Williamson, Lt. Gen. H. R. McMaster, Lt. Gen. Joseph Anderson, and Lt. Gen. John Murray, statement to the Subcommittee on AirLand, Committee on Armed Services,

\footnotetext{
*Corresponding author: Amos C. Fox, Colorado Springs, CO, USA; E-mail: amos.c.fox@gmail.com; Twitter: @AmosFox6
}

Since 2008, Russia's operations throughout Europe, its Near Abroad and Syria signal an evolved approach to the conduct of war. Many terms and phrases have been attributed to Russia's evolved model of war to include Grey Zone conflict and new generation warfare. However, hybrid war or hybrid warfare is quite useful, despite the contention the term generates. The term hybrid warfare is useful because it speaks of the bundling of capabilities, technology and ideas in a coherent, purposeful manner to accomplish tactical, operational and strategic objectives on behalf of policymakers and strategists.

The work starting position is that the Russian hybrid warfare is in fact an applied way of war. Despite many arguments to the contrary, Russia's applied way of war introduces important nuances to the conduct of war. Resultantly, the purpose of this work is to clarify the concept of Russian hybrid warfare and to identify the characteristics that make it worthy of examination.

Two basic methods exist to explain an observable way of war. The first is to paraphrase existing primary source information on the subject. This method requires access to primary source information and the physical ability to read that material. That method is not employed in this work because access to Russian strategic and tactical doctrine is not readily available to the layperson. Furthermore, in many cases doctrine is a preferred way of war-fighting, a narrative and tied to procurement strategies, and thus, not an applied method. Therefore, merely relying on doctrine or policy statements can mislead the researcher about the true character of a given way of war.

That notwithstanding, the second method is to observe the phenomenon in multiple situations over a period of time. In doing so, the observer seeks to identify trends, inconsistencies, rules, relationships, reactions and boundaries that surface and recur therein and then generate an overarching assessment about that phenomenon's boundaries and inner workings. That is the technique employed here.

Keywords: hybrid warfare, Russian hybrid warfare, proxy war, surrogate warfare

United States Senate, on Army Modernization in Review of the Defense Authorization Request for Fiscal Year 2017, Second Session, 114th Congress, 5 April 2016. 


\section{Introduction}

Russia's contemporary approach to war-an amalgamation of information operations, unconventional operations, conventional operations, cyber operations, electronic operations and partisan activities-is used to achieve military objectives aligned with political aims. ${ }^{4}$ Russia's actions, as most recently noted in Montenegro, Ukraine and Syria extend beyond the sole use of conventional military force and steadily increase the employment of proxy actors and the other instruments of national power in the pursuit of political objectives.

Furthermore, Russia's actions demonstrate an acute awareness of strategic time and seek to operate in a step or two ahead of the international community's reaction time. Simultaneously, Russian actions embody restraint through the employment of covert methods to achieve its political and military objectives. However, Russia's actions are unique because of the blended role that conventional forces and conventional combat play within its hybrid model of warfare. The Russo-Ukrainian War's Donbas Campaign, fought from the spring of 2014 through February 2015, is trussed by conventional land warfare fought by Russian-generated proxy forces, intermixed with Russian land forces, against the Ukrainian armed forces and hastily formed militias. During this campaign, several major battles, strikes and sieges took form, to include the siege of Luhansk Airport (April-September 2014), the strike at Zelenopillya (14 July 2014), the siege of Ilovaisk (7 August-2 September 2014), the Second Battle of Donetsk Airport (28 September 2014-21 January 2015) and the Siege of Debal'tseve (14 January 2014-20 February 2015). Meanwhile, several smaller battles early in the war, to include Sloviansk and Kramatorsk, set the Donbas Campaign's arch.

Conventional Russian operations in Ukraine, as a sub-component of Russian hybrid warfare, demonstrate the resurrection of high-intensity combat operations. In Ukraine, Russian land warfare, fought under the umbrella of hybrid war, is characterised by a rapid sensor-to-shooter fire support structure, the offensive employment of field artillery and multiple-launch rockets and the employment of robust combined arms formations that reside in both the tactical and operational levels of war. The by-product of Russian hybrid warfare is the re-emergence of sieges and an attrition-based operational and tactical approach to battle. ${ }^{5}$ Russia's conventional war-fighting capability,

4 Fridman, O. (2018). Russian 'Hybrid Warfare': Resurgence and Politicisation. Oxford University Press, Oxford, pp. 95-97.

5 Fox, A. C. (2017, Winter). The battle of Debal'tseve, the conventional line of effort in Russia's hybrid war in Ukraine. Armor, 128(1). reinvigorated by large capital investment since 2003, yielded a ground combat force with capability not seen in European battlefields since the end of the Cold War. ${ }^{6}$ Specifically, analysis by Andrew Monaghan indicates that:

Russia invested more than $\$ 640$ billion to modernize its force, increasing its capabilities by more than 700 modern attack aircraft, 2000 tanks, and 2000 tracked and self-propelled guns. This includes major upgrades to conventional Russian ground combat platforms such as the T-72B3, T-80, T-90, the BMP-3, and MT-LB family of infantry fighting vehicles and personnel carriers, and the introduction of the T-14 Armata. ${ }^{7}$

Tucked within the US\$640 billion modernization effort are hidden improvements in cyber, electronic and drone capabilities, all of which work in tandem with the conventional and unconventional forces of Russia's military. However, Russian hybrid warfare is deeply rooted in its geopolitical history, its military history, its ethnic composition and its trial with Communism during the twentieth century. ${ }^{8}$ Russian expert Bettina Renz suggests that strong military power has always been central to Russia's self-perception and has been central to each of the major Russian polities throughout its history. ${ }^{9}$ Further, Russia's hybrid warfare is inherently rooted in its national means and its ability to keep money flowing into its economic system. In addition, Russian hybrid warfare is influenced by contemporary technology as well as by the conflicts of the late twentieth century and early twenty-first century, to include US involvement in Afghanistan and Iraq, and revolutions that overturned the political order of the Middle East, Europe and Eurasia. ${ }^{10}$

The most powerful implication is not necessarily in a resurgent Russia, but in providing the world with a modern approach to warfare that merges the instruments of national power within operational design - all of which is nested in time, space and purpose to achieve political objectives. The approach aggregates Information Age technology within this construct to achieve victory

6 Masters, J. (2014, November 14). How Powerful is Russia's Military. Defense One. Available at: http://www.defenseone.com/ threats/2014/11/how-powerful-russias-military/99062. [Accessed 2016, May 9].

7 Monaghan, A. (2015-2016, Winter). Putin's Way of War: The 'War' in Russia's 'Hybrid Warfare. Parameters, 69.

8 Reach, C., Kilambi, V., \& Cozad, M. (2020). Russian assessments and applications of the correlation of forces and means. RAND Corporation, xxi, Available at: https://www.rand.org/pubs/research_ reports/RR4235.html.

9 Renz, B. (2016, Summer). Why Russia is reviving its conventional military power. Parameters, 46(2), p. 26.

10 Reach, et al., Russian Assessments, pp. 109-113. 
without the formal commitment of forces. Information Age technology covers a wide variety of items, to include improvements to information and communications technology, nascent and improved cyber and electronic capabilities and improved anti-access/area-denial capabilities. In short, hybrid warfare is an expanding approach to war that exploits vulnerabilities in nascent technological innovation in relation to an adversary.

As with any way of war, many of the Russian hybrid warfare's peculiarities are inextricably linked to Russia's social, political and economic condition. Nevertheless, Russia's success, coupled with the international community's inability or unwillingness to meaningfully deter its bellicose action since 2008, could embolden other nations or polities with comparable means to institute a similar approach to conflict. ${ }^{11}$ In doing so, Russian hybrid warfare possesses the potential to reshape the face of modern war by making war perpetual, operating in the shadows and being always capable of hastily escalating to full-scale attritional combat.

The Russo-Ukrainian War, discussed briefly later in this work, is the most noticeable and recent example of Russian hybrid warfare. This war and Russian hybrid warfare are best understood by appreciating the impact of former Russian Foreign and Prime Minister Yevgeny Primakov on contemporary Russian strategic and military thought. Primakov's position, commonly referred to as the Primakov Doctrine, rests on a series of pillars.

First, Russia must strive to overturn the unipolar world order and instead advocate for a multipolar world balanced by a collection of major powers. Second, Russia must stop NATO's expansion, specifically in historically Russian areas of interest and involvement. Third, Russia must advocate for primacy in the post-Soviet space. ${ }^{12}$

The Primakov Doctrine set the strategic arch for Vladimir Putin, whose run at the top of Russia began in 1999. Minister of Defence, Sergei Shoygu and Chief of Staff of the Armed Forces, Valery Gerasimov, as well as their forerunners during Putin's administration, weaponised the Primakov Doctrine's strategic framework into an aggressive foreign policy implement. Shoygu and Gerasimov crafted a way of war that accounted for the

11 Bugayova, N. (2020). Putin's Offset: The Kremlin's Geopolitical Adaptation Since 2014. Institute for the Study of War: Military Learning and the Future of War Series. pp. 1718. Available at: http://www.understandingwar.org/report/ putins-offset-kremlin\%E2\%80\%99s-geopolitical-adaptations-2014.

12 Rumer, E. (2019, June). The Primakov (Not Gerasimov) Doctrine in Action. Carnegie Endowment for International Peace, pp. 3-6. Available at: https://carnegieendowment.org/2019/06/05/ primakov-not-gerasimov-doctrine-in-action-pub-79254. sensitivities of the international security environment, while applying feedback from Russia's experiences in Transnistria, Chechnya and Georgia.

Shoygu and Gerasimov's way of war, which in effect is today's Russian hybrid warfare, is underpinned by five basic assumptions. These assumptions are derived from observation and not policy documents, as access to such important documents is highly restrictive. Observation's value comes in its ability to cut through and see beyond the strategic narratives and storylines often found in policy documents.

The first assumption guiding Russian hybrid warfare is underpinned by the idea that the first rule of war is to protect oneself against a decisive blow. ${ }^{13}$ Second, Russia views the rules-based international order as a handrail to exploit, and not as being strategically constraining. ${ }^{14}$ Third, Russia comprehends the international community's clock-its legal processes and the time in which it takes strategic actors to make decisions and subsequently act-and it operates across all elements of national power in such a way as to upend that clock and get itself into a desirable position ahead of the international community's ability to recognise what is happening and respond in any meaningful way to counteract that activity. ${ }^{15}$ Russia tends to side-step this through fait accompli. ${ }^{16}$

Fourth, Russia understands the international community's detection threshold and operates just beneath it or camouflages its activities sufficiently, so as to provide it with time and manoeuvre space. This results in the use of proxies, whether those are contractual proxies such as Wagner Group contractors, or cultural proxies like the Donetsk and Luhansk People's Republic and Army. ${ }^{17}$ Additionally, this results in the use of Russian soldiers in unmarked uniforms, as was the case in Crimea in 2014. ${ }^{18}$

Fifth, Russia understands that shaping activities, if executed properly, can negate the need for conventional combat operations. This is where cyber, information, disinformation and electronic warfare prove useful within Russian hybrid warfare. ${ }^{19}$

13 Svechin, A. (2004). Strategy. East View Information Services, Minneapolis, MN. p. 248.

14 Jensen, D., \& Doran, P. (2018, November). Chaos as a strategy: Putin's "Promethean" Gamble. Center for European Policy Analysis, p. 22. Available at: https://cepa.org/chaos-as-a-strategy/.

15 Ibid., 29.

16 Altman, D. (2017, August). Advancing without attacking: The strategic game around the use of force. Security Studies, 27(1), pp. 12-13. doi: 10.1080/09636412.2017.1360074.

17 Fox, A. (2020, November). Five models of strategic relationship in proxy war. Georgetown Security Studies Review, 8(2), pp. 56-57.

18 Ibid.

19 Bugayova, Putin's Offset, pp. 17-18. 
To summarise, Russian hybrid warfare is a weaponised extension of the Primakov Doctrine, as expressed by the machinations of Defence Minister Shoygu and Chief of Staff Gerasimov. Despite competing narratives about its theoretical and institutional underpinnings, Russian hybrid warfare is an applied way of war that both harnesses and weaponises soft power, hard power, coercive power and digital power into an offensive foreign policy instrument which the Kremlin wields to bring about favourable change. Within its rendering of hybrid warfare, Russia selectively employs the amalgamated power in iterative operations-strategic, operational, and tacticaluntil it brings about a desirable change in the situation, from political to tactical levels.

Beyond Russia, hybrid warfare's potential influence on armed and unarmed conflict is vast, and yet fundamentally dependent on the observer's analytical perspective, or at which level of conflict they choose to focus their attention. At the strategic level, hybrid warfare tends to be the employment of information operations and diplomacy in conjunction with cyber and electronic operations to weaken an opponent, or to sow the seeds of chaos in relation to an adversary. In many circles this is referred to as aktivka, or active measures. ${ }^{20}$ Russian hacking into the 2016 US presidential campaign is an example of this idea. Similarly, the strategic component of hybrid warfare in relation to Ukraine can be seen during the precursor to annexation of Crimea and offensive action in the Donbas, as Russia used information operations and diplomacy to weaken the government in Kyiv.

Operationally, hybrid warfare is the arrangement of tactical actions in time, space and purpose in pursuit of strategic objectives. In hybrid warfare, tactical actions are more than just the combination of offence, defence and stability operations. In several key respects, these actions include cyber and electronic operations targeting an opponent's movement of troops, targeting an opponent's ability to communicate across the front and targeting an opponent's information. In fact, many of the operational cyber and electronic operations prey on the same targets as operational fires, albeit with different means.

Tactically, hybrid warfare represents a return to high-intensity combat operations in which armour, infantry and artillery fight for local dominance of significant terrain. In hybrid warfare, tactical action is a continuance of a campaign if information, cyber, electronic and unconventional operations are unsuccessful in achieving the

20 Jensen, D., \& Doran, P. (2018, November). Chaos as a strategy: Putin's "Promethean" gamble. Center for European Policy Analysis, pp. 24-30. Available at: https://cepa.org/chaos-as-a-strategy/. operational and strategic objectives. The absence of tactical conventional action during the annexation of Crimea signifies this concept, while conventional war-fighting in the Donbas illustrates the latter. To gain a better appreciation for hybrid warfare, it is imperative to analyse the theoretical underpinnings in which the construct develops.

Viewed collectively, hybrid warfare represents the selective and iterative applications of power-hard, soft, digital and coercive-across multiple domains through iterative operations until such a point in which there is favourable change in a situation is achieved. At the operational and tactical levels, the concept represents the rebirth of sieges and proxy war. Moreover, much like the phoenix rising from the ashes, the Russian flavour of hybrid warfare represents the return of attrition-based battle in which victory goes to the side that can exact the highest toll in men, material and political capital.

\section{Hybrid warfare and its theoretical underpinnings}

Many analysts contend that Russian hybrid warfare is not an actual concept and brush aside General Valery Gerasimov's impact on the state of Russian military thought. Dissenting voices often point to the fact that the phrase hybrid warfare is not used in Russian military doctrine or policy papers to describe its own activities. Nevertheless, that absence does not concern the concept's applied presence.

Analyst Michael Kofman routinely points out perceived flaws in the concept, suggesting that high-end warfare vis-à-vis Russia is more important to understand than hybrid warfare. ${ }^{21}$ Meanwhile, analyst Jānis Bērzinšs, relying on Russian literature, contends that the idea of hybrid warfare is a Western theoretical framework and not one that resides within Russian military thought. ${ }^{22}$ However, Bērziñš does state that the post-Soviet Russian way of war is something new. He suggests that the concept is New Generation Warfare and is built on five pillars: asymmetric warfare, a strategy of low-intensity conflict, network centric warfare, sixth-generation warfare and reflexive control. ${ }^{23}$

21 Kofman, M. (2016, March 11). Russian hybrid warfare and other dark arts. War on the Rocks, Available at: https://warontherocks. com/2016/03/russian-hybrid-warfare-and-other-dark-arts/.

22 Bērziņš, J. (2020). The theory and practice of new generation warfare: The case of Ukraine and Syria. The Journal of Slavic Military Studies, 33(3), pp. 358-370. doi: 10.1080/13518046.2020.1824109.

23 Ibid. 
Much like the concept itself, hybrid warfare's definition is a major point of contention within the strategic and defence studies communities. Analyst Frank Hoffman suggests, 'Hybrid wars incorporate a range of different modes of warfare, including conventional capabilities, irregular tactics and formations, terrorist acts... and criminal disorder. ${ }^{24}$ Hoffman continues, stating that hybrid wars are operationally and tactically synchronised and coordinated within an area of operation to achieve 'synergistic effects'. ${ }^{25}$ While a good starting point, Hoffman's definition is slightly outdated.

Theorist Robert Leonhard offers an upgrade to Hoffman's definition of hybrid warfare. Leonhard suggests that hybrid warfare is tied to obtaining asymmetric advantages to enable the attainment of political aims. This is done by undeclared action, combining conventional and unconventional operations and coupling military and non-military actions in an environment in which the distance between strategy and tactics is significantly reduced and where information is critically important. ${ }^{26}$ Leonhard's definition best describes the unique attributes of the Russian brand of hybrid warfare.

Furthermore, hybrid warfare juxtaposes two interdependencies, each of which is anchored on the idea of force. The first interdependency synchronizes the use of force with the domains of war, the levels of war and the components of force. ${ }^{27}$ The second interdependency synchronizes the use of force with time, space and purpose. The by-product of the approach is the creation of multiple assailable or vulnerable flanks which can be attacked or turned for exploitation. The aim of hybrid warfare is to use operations in one domain, with one component of force to set up actions in another domain, and with a different component of force, to create favourable asymmetry at the time and place of one's choosing, while simultaneously

24 Hoffman, F. G. (2007, December). Conflict in the 21st Century: The Rise of Hybrid Wars. Potomac Institute for Policy Studies, Washington, DC, p. 14.

25 Ibid.

26 Leonhard, R. R., \& Philips, S. P. (2015). Little Green Men: A Primer on Modern Russian Unconventional Warfare, Ukraine 2013-2014. US Army Special Operations Command, Fort Bragg, NC, pp. 17-18.

27 "Components of Force" are defined by the author as conventional force, unconventional force, cyber operations, electronic operations, information operations, diplomatic operations, and economic operations. While this idea is similar to the concept of "Forms of Contact," they are different in that 'contact' implies the physical act of force to inflict compliance through subjugation, whereas Components of Force implies the both the physical act of force to inflict compliance and the intangible aspect of force seeking to influence the mind or actions of an adversary. keeping the preponderance of one's force outside of contact or decisive engagement with the threat.

Nevertheless, when the conditions are right, contemporary hybrid warfare can and will employ rugged ground forces for conventional operations that are capable of operating in a dispersed manner, conducting effective air-ground reconnaissance, bringing a suite of fires capabilities to bear at points of opportunity to achieve temporary local or zonal dominance and engaging in pursuit of larger military and political objectives. Ground forces on the hybrid battlefield can operate dispersed through increasing capabilities in lower-echelon formations.

Moreover, theorist Liddell Hart suggests leveraging an opponent's momentum against them to enhance one's own operations. It is certain that consequent to the Information Age technology and the contemporary operating environment, in which the digital, interconnected world is connected 24 hours a day, 7 days a week, the idea of operations has also shifted. Operations are no longer relegated solely to combat but extend to targeted uses of force in the information, cyber and electronic domains, seeking to influence populations, governments and the international community. Therefore, the use of an opponent's effort, or their operations, can be turned against them, or as Liddell Hart states, 'As in ju-jitsu, his own effort is turned into the lever of his overthrow. ${ }^{28}$ The use of information operations in relation to hybrid warfare personifies Liddell Hart's idea of the indirect approach and in using an adversary's normalized response against them. These ideas lay the foundation for operations in hybrid warfare, but the real key in war is to be found in sequencing operations.

Theorist Robert Leonhard suggests that the best path to victory in war is through the sequencing of operations, a process he posits as the ordering of events in time, space and purpose. ${ }^{29}$ He suggests that the key to mastering the concept of sequence is to discard the idea that war will be won in a single powerful, decisive operation, because history says that war is instead resolved in multiple, discrete engagements, battles and campaigns. ${ }^{30}$ Therefore, the imperative is not seeking decisive battles of annihilation, but in planning sequenced operations that apply pressure continually until the enemy has been depleted to the point of culmination.

Russian hybrid warfare, which purposefully leverages power through iterative, sequenced operations to bring about desired change, embodies Leonhard's idea.

\section{Ibid., 146.}

29 Leonhard, R. R. (1994). Fighting by Minutes: Time and the Art of War. Praeger, Westport, CT, p. 92.

30 Ibid. 
Hybrid warfare, as Russian actions in Crimea, and to a lesser degree in the Donbas, demonstrates the power of sequence. Further, if one views the Russian idea of 'victory' in terms of the continued existence of the people's republics in Donetsk and Luhansk, coupled with a weakened Kyiv, then Russian actions in Ukraine, as they relate to sequence, gain far more value.

\section{Russian hybrid warfare's strategic context}

Beyond military theory, the spectre of nuclear engagement is a critical component of Russian strategy and hybrid warfare. ${ }^{31}$ As Dmitry Adamsky writes, 'The nuclear component is an inseparable part of Russian operational art that cannot be analyzed as a stand-alone issue' because it serves to embolden Russian aggression through its deterrence to adversarial counteraction. ${ }^{32}$ Resultantly, the spectre of nuclear weapons on war has forced adversaries to seek other methods and areas in which to advance the pursuit of their interests. This has given rise to the use of force moving beyond the physical domain and into more intangible domains such as cyber, electronic, information and space. ${ }^{33}$ This idea has also driven the use of more indirect means and methods as the primary conduit for an actor to accomplish their respective ends.

As a result of nuclear weapons' governing effect on war, technological innovation is at the epicentre of modern hybrid warfare because it allows an actor to aggressively engage an opponent, while operating below the threshold of armed conflict. Technology has then allowed the use of force to not only move beyond the confines of the physical domain, but also to other intangible and abstruse fields. These characteristics serve to energize modern hybrid warfare and give it form.

Furthermore, a grounding in strategy is germane to the understanding of Russian hybrid warfare. One problem with strategy is that there is no clear or universally accepted definition of the term. In asking any theorist, strategist, historian or practitioner of war for a definition of strategy, it is likely that as many answers

31 Ven Bruusgaard, K. (2020, October). Russian nuclear strategy and conventional inferiority. Journal of Strategic Studies, 44(1), pp. 2-3. doi: 10.1080/01402390.2020.1818070.

32 Adamsky, D. (2015). Cross-domain coercion: The current Russian art of strategy. Proliferation Papers 54. Institut Francais des Relations Internationales Security Studies Center, Paris, p. 9.

33 Watling, J. (2020, July). By parity and presence: Deterring Russia with conventional land forces. RUSI Occasional Paper, pp. 2-5. would be obtained. Nevertheless, theorist Carl von Clausewitz defined strategy as the use of engagement to achieve the objectives of war. ${ }^{34}$

On the other hand, the US military defines strategy as, 'A prudent idea or set of ideas for employing the instruments of national power in a synchronized and integrated fashion to achieve theater, national, and/or multinational objectives. ${ }^{35}$ It further refines this definition to a simple formation, stating that strategy is the balanced application of ends, ways and means to accomplish or achieve policy aims. ${ }^{36}$ However, neither of those discussions on strategy provides the granular insight to understand how and why nations approach war in the way they do. A more detailed understanding of strategy better will facilitate a better appreciation for the utility of the concept of hybrid warfare.

Historian Lawrence Freedman provides an enhanced model for understanding strategy. Freedman writes that the purpose of strategy is to transition from short-term, trivial thinking to long-term and essential thinking in relation to a problem-set and to address causes, rather than symptoms of those problems. ${ }^{37}$ Moreover, Freedman contends there are three conditions in which strategy is required. The first condition is when the potential for conflict exists. The second condition is when actual conflict exists. The final condition arises when opposed interests intersect and resolution is required. Freedman contends that strategy must be amorphous and agile, taking shape from the starting conditions and be responsive to the inherent means of the polity for which it serves. Strategy must also be inherently tied to a political act, which is focused on extracting more from a situation than the starting conditions would suggest is achievable. Lastly, strategy is a study of the relationship between time, positions, means and different interests. ${ }^{38}$ Freedman's discussion of strategy provides the most useful tool in understanding the strategic context for Russia's employment of hybrid warfare.

Russian security-thinking assumes that the nation is surrounded by enemies and therefore must maintain a

34 Clausewitz, On War, 128.

35 Joint Publication (JP) 1-02. (2011). Department of Defense Dictionary of Military and Associated Terms. Government Printing Office, Washington, DC, p. 350.

36 Lykke, A. F. Jr. (2008). Toward an understanding of military strategy. In: Boone Bartholomees, J. Jr. (ed.), The US Army War College Guide to National Security Issues 2. Strategic Studies Institute, Carlisle Barracks, PA, p. 179. 37 Freedman, L. (2013). Strategy: A History. Oxford University Press, New York, p. ix.

38 Ibid., pp. ix-xii. 
territorial buffer to protect Russian sovereignty. ${ }^{39}$ Additionally, Russia seeks to bring about a new era of geopolitics to reshape the global balance of power and to tip the balance in its favour. ${ }^{40}$ Key components of this are the protection of ethnic Russians, protection of Russian economic interests and continued occupation of former naval and army bases. ${ }^{41}$ Three strategic objectives are derived from Russia's political objectives, which are the following, namely to deter NATO expansion into Russia's historic sphere of influence, to retain regional hegemony in Eurasia and to demonstrate improvements to Russian military capabilities. ${ }^{42}$ Each of these strategic Russian objectives, coupled with the ideas embodied within the Primakov Doctrine, is emboldened by the strategic defence provided by its nuclear capabilities and its integrated air defence system throughout Eastern Europe, which must be viewed in relation to the contemporary era of limited conflict.

Considering Russian security thinking, the country developed a whole-of-government, multiple-domain approach to warfare to accomplish its political and strategic aims. Russian hybrid warfare reflects the experience it gained from its post-Soviet military conflicts, coupled with its observation of American capabilities development and American intervention throughout the world since the fall of the Soviet Union. Russian actions in Ukraine, which include the annexation of Crimea and the Donbas, clearly demonstrate Russia's applied theory of hybrid warfare.

Russia has never fully accepted Ukrainian independence, and instead views it as a subordinate state. Although it gained its independence following the collapse of the Soviet Union in 1991, Russia has continued to try and exert influence over the geographical regions that once constituted the country - politically, militarily, socially and economically. Additionally, many ethnic Russians are located within Ukraine, primarily located in the Donbas Region and Crimea. Nevertheless, this situation is onelargely of Russian creation. While Crimea has traditionally been part of the Russian empire, it was given to Ukraine for political purposes in 1954 by the then USSR-Premier Nikita Khrushchev. On the other hand, the Donbas' ethnic diversity was

39 Reed Anderson, R., Ellis, P. J., Paz, A. M., Reed, K. A., Renegar, L., \& Vaughn, J. T. (2016). Strategic Landpower and a Resurgent Russia: An Operational Approach to Deterrence. US Army War College Press, Carlisle Barracks, PA, p. 13.

40 Kagan, F. W., \& Kagan, K. (2015, September 27). Putin ushers in a new era of global geopolitics. Institute for the Study of War.

41 Clapper, J. R. (2016). Director of National Intelligence, speaking to the Senate Armed Services Committee on Worldwide Threat Assessment of the United States Intelligence Community on February 9, 2016, pp. 17-18.

42 Ibid. created by the then USSR-Premier Joseph Stalin following World War II as he relocated thousands of Russian citizens to the area to create an enclave in the region, which would enable Kyiv's social and political manipulation. ${ }^{43}$

Russia's strategic objectives laid the foundation for its annexation of Crimea, which immediately preceded the Russo-Ukrainian War; this act is perhaps the apogee of the theoretical concept of hybrid war in that Russia acquired its strategic objective of Crimea with nearly no kinetic activity. Both conflicts-the annexation of Crimea and the Russo-Ukrainian War-were a result of disagreements over the political direction of Ukraine. Ukrainian President Viktor Yanukovych, who was seen by the Ukrainian people as a Russian puppet, opted for closer ties with Russia, whereas the citizens in western and central Ukraine advocated for closer ties with the European Union. Most citizens in eastern Ukraine, specifically the Donbas and Crimea, supported Yanukovych's position. ${ }^{44}$ This situation created political turmoil in Ukraine, leading to the political revolution known as the Euromaidan movement and the ousting of Yanukovych as president in February 2014. ${ }^{45}$

Information warfare-the foundation of Russia's hybrid campaign for Crimea and the Donbas-began at this time. Russia used the political situation in Kyiv to agitate ethnic Russians, alleging that the western leaning government in Kyiv was unresponsive to and unrepresentative of ethnic Russians in Ukraine. Russia used a variety of means to wage information operations - from television to the Internet, to unconventional forces on the ground spreading the message word-of-mouth. Information operations were successful in further exacerbating the political situation, which Russia used as pretence to annex Crimea under the guise of seeking to protect ethnic Russians.

Economics played a large role in the situation with Ukraine and Crimea. As the Euromaidan movement gained steam, Russia forgave US $\$ 15$ billion in Ukrainian debt to help Yanukovych's political situation. However, when Yanukovych was ousted from office, Russia eliminated

43 Pifer, S. (2020, March 17). Order from Chaos, Crimea: Six years after illegal annexation. Brookings Institute. Available at: https://www.brookings.edu/blog/order-from-chaos/2020/03/17/ crimea-six-years-after-illegal-annexation/.

44 Berzins, J. (2014, April 2-3). Russia's New Generation Warfare in Ukraine: Implications for Latvian Defense Policy, National Defense Academy of Latvia: Center for Security and Strategic Research, Policy Paper no. 2.

45 Ukrainian MPs Vote to Oust President Yanukovych. BBC News, February 22, 2014. Available at: https://www.bbc.com/news/ world-europe-26304842. 
the discounted rate at which it sold natural gas to Ukraine from GazProm. In addition, GazProm incrementally increased its rates to Ukraine by $40 \%$ in March 2014 and another $10 \%$ by April 2014. Shortly thereafter, Russia cut all GazProm sales to Ukraine under the condition that it ought to repay over US $\$ 2$ billion in previous debts. ${ }^{46}$

Unconventional operations were the primary method employed to seize Crimea. However, the annexation also occurred during pre-planned Russian military exercises in the area, which obscured troop movements during the annexation. ${ }^{47}$ On 27 February 2014, Russian infantry seized the Crimean parliament and cabinet ministers' headquarters in Simferopol, Crimea's capital. Later that evening, Russian special operations forces and airborne troopers seized airports in Simferopol and Sevastopol. On 28 February 2014, Russian forces and local partisans seized the state television company and primary telephone and Internet service providers, allowing Russia to control the flow of information within the peninsula. The Russian navy surrounded the Ukrainian fleet at Novoozerne, on the western bank of the peninsula. They then sank a Ukrainian naval vessel, essentially sealing off the Ukrainian fleet at their naval base, thus removing them as a threat from the battlefield. The isolation of the Ukrainian fleet at Novoozerne allowed Russia's fleet at Sevastopol to dominate the Black Sea. On 6 March, Russian forces continued their consolidation of Crimean media by occupying all media outlets in Simferopol, enabling them to run an uninterrupted information-operation. On 15 March, Russian forces seized control of the only natural gas pipeline and distribution centre that supplied Crimea, denying Ukraine the ability to influence the situation in Crimea through the manipulation of natural gas in the peninsula. By 20 March 2014, Ukraine officially ceded Crimea and withdrew its 25,000 soldiers from the peninsula. ${ }^{48}$

\section{Hybrid warfare in the Russo- Ukrainian war}

Russian operations in Ukraine's Donbas ushered in an updated approach to war. One study suggests that Russia's approach to hybrid warfare is 'a truly synchronized

46 Pifer, Order from Chaos.

47 Marsh, C. (2017). Developments in Russian special operations: Russia's Spetsnaz, SOF, and special operations command. 17 Wing Winnipeg Publishing Office, Ottawa, ON, pp. 21-22.

48 Pifer, Order from Chaos. whole-of-government approach to warfare' and that the lines between war and peace have become blurred. ${ }^{49}$ Furthermore, Russia's operational approach synergized information, cyber warfare, electronic warfare and unconventional and conventional operations in all the domains of war, with all the instruments of national power, to achieve their military and political objectives while simultaneously maintaining deniability.

Following the annexation of Crimea, the RussoUkrainian war took on a conventional flavour at the operational and tactical levels of war. Although primary source material pertaining to the Crimean annexation indicates that Russia labelled their action as summer and fall-winter campaigns, astute observation of the conflict does in fact illuminate two distinct campaigns in the Donbas. The campaigns can easily be referred to as the summer campaign of 2014 and the fall-winter campaign of 2014-2015. The campaigns were the result of Russian proxies losing ground in the Donbas. Battles such as Slovyansk, Kramatorsk and First Donetsk Airport demonstrated that without the element of surprise, Russian proxy forces were unable to overthrow Ukrainian forces unilaterally. As a result, the summer of 2014 brought with it a shift in Russian operations and tactics within the Russian hybrid warfare model. Russia transitioned from operating in the shadows to adopting a more overt position. The 11 July 2014 strike at Zelenopillya was arguably the first shot in the summer campaign's opening salvo.

\section{Summer campaign 2014}

During the early morning hours of 11 July 2014, Russian rockets eradicated multiple Ukrainian units mustered to counter Russian proxies in Luhansk Oblast. ${ }^{50}$ This rocket attack, which was reported to come from across the Russian border and consist of BM-21 Grad and Tornado-G Multiple Launch Rockets, was one of the first overt Russian attacks. ${ }^{51}$ Since many years have passed since the time of the incident, numbers are hard to confirm,

49 Squadron, A. (2016, August). Russian new generation warfare. Journal of Asymmetric Warfare, 1(2). pp. 3-4.

50 Weiss, M., \& Miller, J. (2014, July 17). Russia is firing missiles at Ukraine. Foreign Policy, Available at: https://foreignpolicy. com/2014/07/17/russia-is-firing-missiles-at-ukraine/.

51 Woodford, S. (2017, March 29). The Russian artillery strike that spooked the U.S. army. The Dupuy Institute, Available at: http://www.dupuyinstitute.org/blog/2017/03/29/ the-russian-artillery-strike-that-spooked-the-u-s-army/. 
but reports indicate that upwards of four Ukrainian brigades were destroyed in the strike and that they suffered approximately 30 killed in action. ${ }^{52}$ This attack signified a sea change in how Russia was addressing its hybrid war in Ukraine - Russia had moved out of the shadows to preserve the gains it made in Eastern Ukraine, because its proxy was proving unreliable and unable to maintain the gains made in the Donbas.

Additionally, Russia stepped up its support to its proxy forces at Luhansk Airport, which had been under siege since April 2014. The arrival of Russian forces in August, which matched support in Donetsk, broke the back of the Ukrainian forces attempting to hold the airport. By 1 September 2014, Russia and its proxies forced the Ukrainians to vacate the destroyed facility. ${ }^{53}$

In Donetsk, the siege of Ilovaisk served as the summer campaign's bookend. Ukrainian forces fought to retake the city through the month of August. By 28 August 2014, Russian land forces were on the ground at Ilovaisk, which fundamentally changed the situation in favour of Russia and its proxies. A multiple-day siege ensued and when all military operations had been concluded, it could be ascertained that 366 Ukrainian soldiers were killed, another 429 were wounded and approximately 300 were captured. The siege also destroyed 600 of 1800 residential homes in the city, as well as 116 multi-story buildings..$^{54}$

The summer campaign's success triggered the Minsk Protocol, a temporary ceasefire of sorts, between the Russian proxies and Ukrainian forces. ${ }^{55}$ The summer campaign demonstrated a significant shift in Russian hybrid warfare. During the conflict's initial period, Russia focused on remaining in the shadows by using information operations to influence the population, while employing proxies to do their bidding. However, as government forces retook land from the proxies, Russia had to step out of the shadows and fight Kyiv's forces directly. They

52 Bellingcat Report - Origin of artillery attacks on Ukrainian military positions in eastern Ukraine between 14 July, 2014 and 8 August, 2014. Bellingcat, February 15, 2015. Available at: https://www.bellingcat.com/news/uk-and-europe/2015/02/17/origin-of-artillery-attacks/. 53 Ukraine troops quit Luhansk Airport, accusing Russia of turning the tide of war. Euro News, September 1, 2014. Available at: https:// youtu.be/WRKilxAPNmI.

54 Office of the United Nations High Commissioner for Human Rights, "Human Rights Violations and Abuses and International Humanitarian Law Violations in the Context of the Ilovaisk Events in August 2014," United Nations, Available at: https://www.ohchr.org/ Documents/Countries/UA/ReportOnIlovaisk_En.pdf.

55 Allan, D. (2020, May). The Minsk Conundrum: Western policy and Russia's war in Eastern Ukraine. Chatham House, pp. 10-11, Available at: https://www.chathamhouse.org/2020/05/ minsk-conundrum-western-policy-and-russias-war-eastern-ukraine. still attempted to provide a degree of anonymity for their forces, but removing uniform markings was not enough to keep their presence under concealment. The summer campaign's vicious end served as a portend to the winter campaign.

\section{Winter campaign 2014}

The winter campaign picked up where the summer campaign left off. Russia was unable to fully depend on its Donbas proxy forces, for which reason it became fully committed to providing land force support to maintain its gains in Eastern Ukraine. Although smaller skirmishes and battles were fought during this time, the winter campaign's major battles were the Second Battle of Donetsk Airport and the siege of Debal'tseve.

The Second Battle of Donetsk Airport, which also took the form of a siege, began in late September 2014. As a result of the First Battle of Donetsk Airport in May, Ukrainian forces held the airport. On 28 September, Russian proxies in Donetsk set out to wrest the airport from the Ukrainians. The Russian proxies encircled the airport, with the only exclusion of a small artery that was left open from the airport to the outside world. This artery allowed the Ukrainians to ferry men, weapons, equipment and supplies to the airport's surrounded defenders. Nevertheless, the Russian-backed proxies maintained their siege and slowly eroded Ukrainian combat power. In mid-January 2015, a series of combined Russian-proxy assaults resulted in the defence's collapse. ${ }^{56}$ By 21 January, 'little Stalingrad', as the Second Battle of Donetsk Airport became known, was over.

As the siege at Donetsk Airport ended, the siege of Debal'tseve was heating up. Debal'tseve, the nexus of important supply lines that linked Donetsk and Luhansk Oblasts, was acquired in April 2014 by Russian proxies, during the initial phase of Russia's hybrid campaign in the Donbas. Ukrainian forces retook the city from the proxies in July 2014. On 14 January 2015, Russian land forces and their proxies encircled the city and began to saturate it with salvos of rocket fire. During the course of the next 3 weeks, the situation for the Ukrainians rapidly deteriorated, resulting with their defeat on 20 February 2015. The winter campaign resulted in the Minsk II protocol, which

56 Fox, A. (2019, May). Cyborgs at Little Stalingrad: A brief history of the battles of the Donetsk Airport, 26 May 2014 to 21 January 2015. Institute of Land Warfare 125, pp. 5-11. Available at: https://www. ausa.org/sites/default/files/publications/LWP-125-Cyborgs-at-LittleStalingrad-A-Brief-History-of-the-Battle-of-the-Donetsk-Airport.pdf. 
was yet another feeble attempt at a ceasefire between the warring parties. ${ }^{57}$

\section{Summarizing the Donbas strategy}

Russia's Donbas strategy, book-ended by the summer and winter campaigns, proved politically decisive. By July 2020, Moscow, Kyiv and the Donetsk and Luhansk People's Republics all but agreed to the status quo position of forces and political arrangements in the Donbas. ${ }^{58}$ The Donbas operation demonstrates Russian hybrid warfare's dexterity - when information operations, cyber operations and covert activity no longer advanced Russia's policy objectives in Ukraine, they rapidly transitioned to outright, but undeclared, land war. Further, and in support of Leonhard's supposition on sequence, the Donbas operation demonstrates that a successful concatenated sequence of battles and campaigns tends to lead to politically decisive results.

Russian hybrid warfare in the Donbas also demonstrates that modern wars tend to be undeclared because today's technology has reduced the distance (spatial, temporal and informational) between forces and those who control the forces, a byproduct of which is the shrinking of distance between the strategic, operational and tactical levels of war. Additionally, technology has increased the non-military means for achieving political and strategic goals, and those means have largely surpassed common weaponry in terms of utility in that environment. Furthermore, technology today has created a larger information space than existed in the past; this space is nascent, illdefined and not well understood. Therefore, the information space creates an arena in which asymmetric advantages can be attained. ${ }^{59}$

Next, Russian military means, largely consisting of concealed operations through the use of unconventional forces, supplement the non-military means of waging war, the goal being plausible deniability for political leaders. However, the use of conventional forces, as and when these are employed, integrates technology, specifically drones and cyber capabilities, to enhance their effectiveness on the battlefield. Peacekeeping is - in a given environment-a guise and pretence for the commitment

57 Allan, D. The Minsk Conundrum, pp. 10-11.

58 Press Statement of Special Representative Grau After the Regular Meeting of the Trilateral Contact Group on 23 July 2020. Office of Security and Cooperation Europe, July 23, 2020, Available at: https:// www.osce.org/chairmanship/457885.

59 Leonhard and Philips, Little Green Men, 18. to employment of military means, leveraging information asymmetry and political or ethnic schisms. ${ }^{60}$

Finally, the Russian hybrid warfare framework hearkens to Russia's past. The framework states that modern operations, like the forms and methods of Russia's past, must focus on rupturing the enemy's front, and on conducting deep operations through the depth of the enemy's being, whether or not it be a military formation. Moreover, Russian hybrid warfare demonstrates that deep operations are the framework for contemporary operations, but the approach must seek to leverage the capabilities of modern technology, and strike from long distances, with contactless action. ${ }^{61}$

\section{Impact of hybrid warfare for war in the present and future}

The Russian hybrid warfare model provides policymakers and practitioners valuable lessons. First, it demonstrates that nation-states are still inclined to invest in powerful conventional capabilities that are centred upon rugged ground forces to deter potential threats, lending legitimacy to the government and defending their borders if threatened..$^{62}$ Defence analyst Bettina Renz suggests the retention of powerful conventional forces is the result of the fact that modern nations feel that these capabilities enhance their perception as a 'strong state', lending them more credibility as participants on the global stage. Therefore, Russia's reinvestment in conventional capabilities seeks to adjust the balance of power in Europe towards Moscow. ${ }^{63}$ Conversely, this action capitalises on Europe's divestiture of conventional forces since the fall of the Soviet Union. Moreover, investment in those capabilities, as demonstrated by the Battalion Tactical Groups (BTGs), shows that conventional capability is a key part of hybrid warfare.

Next, the strategic, operational and tactical levels of war are interconnected and actions or innovations at one level influence the others. These innovations do not occur in isolation and are often direct responses to conditions or perceived conditions arising from the battlefield

60 Ibid.

61 Gerasimov, V. (2016, January-February). The value of science is in the foresight: New challenges demand rethinking forms and methods of carrying out combat operations. trans. Robert Coalson, Military Review, 96(1), pp. 24-25.

62 Renz, B. Why Russia is reviving its conventional military power. 24.

63 Ibid. 
or threat analysis. The point is that as other nation-states or up-and-coming polities aim to solve their problems, or look for effective ways in which to achieve their interests, they will probably pursue innovation in a similar manner.

Hiding beneath the veneer of hybridity are powerful conventional capabilities, as Russia demonstrated in Ukraine in 2014. ${ }^{64}$ Russia's tactical innovation in relation to their ground combat formation is one such instance in which tactical innovation influences operational thought, specifically in the areas of campaign planning and sequencing of operations. Analysts suggest that Russia has reorganized its tactical formations-specifically, their battalion- and brigade-level organisations-to generate forces that possess the ability to punch well above their relative echelon. ${ }^{65}$ Russia, recognising the importance of tactical dispersion and the efficacy of manoeuvre warfare, coupled with the understanding of the increased lethality and range of modern weaponry, reorganized its ground combat formations. In doing so, they moved the battalion-level unit to the forefront, and developed BTGs that are equitable to US Army Armored Brigade Combat Teams and are capable of operating along comparable ranges to include up to $40 \mathrm{~km} .{ }^{66}$

The most important factor that can be deduced from examining Russian hybrid warfare is the relationship between limited war, nuclear deterrence, information operations and conventional capabilities. The presence of nuclear weapons is perhaps the first critical component for modern hybrid warfare. Nuclear weapons provide insurance against a massive ground response to an incremental, limited war. The offensive nation that possesses nuclear weapons knows that the adversary or its allies will probably not commit large ground forces to a conflict for fear of the aggressor employing those weapons against ground forces. This dynamic emboldens the aggressor nation. In the case of Russia, its possession of nuclear weapons emboldens leaders to take offensive action, because they know that even the threat of nuclear employment backs potential adversaries to a standstill.

Next, the idea of sequence surfaces. Leonhard suggests, "Victory in warfare is linked inextricably with positive control of sequence. Nor is the link spurious or coincidental: the side that successfully strives to order future events will be the side that emerges victorious. ${ }^{67}$ As the Donbas operation illustrates, during periods of

64 Monaghan, A. (2015-2016, Winter). Putin's Way of War: The 'War' in Russia's 'Hybrid Warfare'. Parameters, 45(4), 68.

65 Fox and Rossow. Making Sense of Russian Hybrid Warfare, pp. 5-11. 66 Ibid.

67 Leonhard, Fighting by Minutes, p. 103. limited war, in which the rapid acquisition of limited objectives is of vital importance, the sequencing of operations gains even more utility because it necessitates quick action nested with a balanced use of ways and means. Modern technology, integrating contemporary limited war, and Leonhard's musings on sequence, indicate that sequencing contemporary operations is no longer solely dependent on the ability for fuel and food to maintain pace with ground combat elements. Russian operations in Ukraine demonstrate how operations can be sequenced in time, space and purpose in multiple domains. Sequence no longer rests on the ability to continue with the physical employment of force, but rather on layering operations in depth through use of a blending of information, cyber, electronic, unconventional forces and conventional forces.

Conversely, sequence is the key for defeating an integrated defence. As Russian operations illustrate, nation-states with integrated defence systems, typically established after incremental territorial advances over time, will be able to establish a robust defensive position to retain their territorial conquests and to retain freedom of manoeuvre. Most militaries, including that of the United States, have not had to account for this situation in decades and largely lack the experience and requisite knowledge to plan accordingly. ${ }^{68}$ Furthermore, operational and tactical planners have not had to plan for operations in contested environments in which air superiority or domain dominance is not guaranteed. Also, planners have not developed campaigns against ground forces that have such qualitative and quantitative advantage as the BTG. Therefore, the idea of sequenced operations to defeat integrated defensive networks must be a component of thinking in relation to hybrid wars of the future.

As discussed in Latvian defence documents, 'To what extent is NATO's legal framework ready to deal with modern warfare. ${ }^{69}$ Specifically, Russian hybrid warfare, or to borrow the Latvia term 'modern warfare', carried out in Crimea operated beneath the threshold of the NATO Article-5-retaliation, but still constituted an attack and territorial acquisition of another nation. Although Ukraine is not a member of NATO, and thus not provided with Article 5 protection, the effectiveness of the Crimean annexation will encourage future situations to unfold in a similar manner, in which an actor seeks a limited military objective within another and uses hybrid warfare

68 Gen. Mark A. Milley. (2016, June 26). Priorities for our nation's army. Lecture, Center for Strategic and International Studies, Washington, DC.

69 Berzins. Russia's New Generation Warfare in Ukraine, p. 1. 
to conceal the offensive, before quickly transitioning to an operational or strategic defence after achieving those objectives, to put themselves in a position of advantage in pursuit of the political aim. Theorist Dan Altman's work on the efficacy of fait accompli echoes this assessment. Altman's work contends that in the post-World War II era, fait accompli is the primary form of territorial acquisition in limited war scenarios. ${ }^{70}$

Coinciding with operating below the threshold of NATO retribution and that of the international community is the idea of not operating as a joint force. The RussoUkrainian War illustrates the efficacy of non-joint operations in relation to hybrid warfare in that it minimises an aggressor's footprint, increasing the ability to deny involvement in combat operations in pursuit of strategic objectives. The absence of joint operations is not to say that operations in the air domain are not being conducted, since hybrid warfare demonstrates quite the contrary. To make up for the absence of joint air power or army aviation, hybrid threats will increasingly rely on drones. These will continue to serve as reconnaissance platforms and will likely become equipped with firepower as hybrid threats continue to evolve. Additionally, one can expect to see the use of armed drones exported to proxy, or partisan forces, to enable the hybrid aggressor to continue to pursue a policy of deniability. These armed drones will work in tandem with proxy, partisan and unconventional forces for information collection and targeting purposes, in pursuit of strategic objectives.

\section{Conclusion}

Hybrid warfare is an offset strategy to exploit an adversary's vulnerabilities, to include internal political, social and economic divisions. Hybrid warfare embraces strategist Everett Dolman's concept of strategy, which posits that 'Strategy, in its simplest form, is a plan for attaining continuing advantage', the purpose of which is continued advantage for the state. Furthermore, Dolman's position postulates, 'Stringing together anticipated outcomes is the essence of applied strategy. ${ }^{71}$ Russian hybrid warfare aligns with Dolman's concept of strategy as Russia abides by the idea of perpetual conflict due to the presence of a

70 Altman, D. (2017, December). By fait accompli, not coercion: How states wrest territory from their adversaries. International Studies Quarterly, 61(4), pp. 881-891. doi: 10.1093/isq/sqx049.

71 Dolman, E. C. (2005). Pure strategy: Power and principle in the space and information age. Routledge Press, New York, p. 5. permanent enemy, which currently is the United States and Western culture and its values, political system and ideology. ${ }^{72}$

Hybrid warfare supports limited wars in which actors do not pursue strategies of annihilation, but instead look to impose their political will without destroying their adversary's political institutions. Hybrid warfare supports Information Age innovation. It operates in multiple domains to find methods to achieve a relative position of advantage or conduct operations aimed at weakening the adversary, from the inside-out. Hybrid warfare does this by blending the instruments of national power, information operations, cyber and electronic operations, unconventional operations and conventional operations, as needed or able to do so, in pursuit of this aim.

Hybrid warfare seeks to win without fighting in the physical sense. In the event this is unsuccessful, hybrid warfare, at least as embodied by Russia, initiates a conventional line of operations to further advance its interests and to pursue the political and strategic agenda that are associated with this form of warfare, as illustrated by Russia's Donbas campaign.

The concept of hybrid warfare is built upon the idea of perpetual conflict and the ideological motivation that tactical or operational victory is less important than maintaining a position of perpetual advantage. Russia's Novorossiya movement in the Donbas reflects this idea by carving out a polity that is sympathetic-if not subservient-to Russia in the Donbas, while significantly weakening Ukraine. Some view the Russian expedition into the Donbas as a failure, its result being 'frozen conflict'. Others view the campaign and its resulting conditions to be a success since it has significantly weakened the Ukrainian government and its armoured forces, providing a pliable neighbour on NATO's periphery. The success of Moscow and the Donetsk and Luhansk People's Republics (DPR and LPR) during the 23 July 2020 Trilateral Cooperation Group meeting with Ukraine, which confirmed the existing lines of demarcation, as well as affirmed the DPR and LPR as the break-away regions' ruling bodies, illustrates the concepts utility in modern war. ${ }^{73}$

Finally, hybrid warfare operates on the assumption that wars of annihilation are a thing of the past due to the governing factor that nuclear weapons play. Wars of annihilation, or regime change, often create more turmoil

72 Berzins. Russia's New Generation Warfare in Ukraine. p. 5. 73 "Press Statement of Special Representative Grau" Office of Security and Cooperation Europe. 
for the aggressor, and therefore, the goal of hybrid warfare is to not topple existing regimes, but instead to create national ulcers that perpetually suck resources and political power away from an opponent's capital. These ulcers are tools which the aggressor can ratchet up, as needed, to apply political pressure on its opponent. ${ }^{74}$ These frozen conflicts are alive and well in many parts of the world

74 Bugayova, Putin's Offset, 25. and have been a tool of the Russians since the demise of the Soviet Union. ${ }^{75}$ However, as more local powers seek to expand regionally and beyond, they will probably use hybrid warfare to create enclaves of support within their neighbours' territory, using alleged concerns such as similar ethnic heritage or interests as a pretence for involvement. 